\title{
Pattern of Presentation and Outcome of Surgical Management of Primary Open Angle Glaucoma in Kano, Northern Nigeria
}

\author{
A. Lawan \\ Department of Ophthalmology, Faculty of Medicine, Bayero University Kano, Nigeria \\ Reprint requests to: Dr. Abdu Lawan, Department of Ophthalmology, Aminu Kano Teaching Hospital, Kano, \\ Nigeria. E-mail: lawal1966@yahoo.com
}

\begin{abstract}
Background: Primary open angle glaucoma (POAG) is one of the leading causes of avoidable blindness. Unlike blindness from cataracts, glaucomatous optic nerve damage is irreversible, and prevention of glaucoma is one of the priorities of World Health Organization (WHO) Vision 2020 program. POAG is the commonest type of glaucoma and affects about 33.1 million people worldwide. This study is a five year review of 71 eyes of 63 patients who had trabeculectomy. The study evaluates the pattern of presentation and modality of surgical treatment in our environment.

Methods: Records of all patients with primary open angle glaucoma operated over a five year period was retrieved. Information extracted included patients bio data, visual acuity, gonioscopic findings, intra ocular pressure as measured with applanation tonometer before and after surgery, and recorded in $\mathrm{mmHg}$. Perimetry was done with $2 \mathrm{~m}$ tangent screen and recorded in a perimetry chart. All the patients had trabeculectomy with application of anti metabolite (5fluorouracil). Extra capsular cataract extraction with or, without posterior chamber intra ocular lens implantation was done on 13 patients. Biometry was not done on patients with cataract. Surgery was done on better eye first in all patients.

Results: There were 71 eyes of 63 patients. The male to female ratio was 3:1. The age ranged between 18 to 75 years. 8 patients were below the age of 30 years. One third of the patients were between the ages of 50 to 59 years. At presentation 12 patients (19\%) had normal vision (WHO vision category O), 26 patients (41\%) were visually impaired, 12 patients (19\%) were severely visually impaired and 13 patients (21\%) were blind (from co existing cataracts). The cup disc(c: d) ratio assessed before surgery was 0.5 in 9 eyes $(13 \%), 31$ eyes $(53 \%)$ had c: $d$ ratio 0.6 to 0.8 and 18 eyes had $\mathrm{c}$ : $d$ ratio of 0.9 . All the patients had open anterior chamber angles (Schafer grade 3 and 4). Perimetric changes were; mild peripheral constriction in 5 eyes (8\%), peripheral constriction with arcuate scotoma in 19 eyes $(26 \%)$, constricted fields of $30^{\circ}$ or less in 34 eyes (48\%), and in 13 eyes there was inability to fixate on target. IOP before surgery was 21 to $30 \mathrm{~mm} \mathrm{Hg}$ in 12 eyes (17\%), and above $31 \mathrm{~mm} \mathrm{Hg}$ in 69 eyes (83\%). Post operative IOP of 10 to $15 \mathrm{~mm} \mathrm{Hg}$ was obtained in 58 eyes (82\%) and 11 eyes (15\%) had IOP of 16 to $20 \mathrm{~mm} \mathrm{Hg}$. Only 2 eyes (3\%) had IOP in the lower twenties.

Conclusion: Primary open angle glaucoma is characterized by late presentation. Trabeculectomy with application of $5 \mathrm{FU}$ is the surgical treatment of choice in our environment and give good intra ocular pressure control. There is need to increase public awareness on glaucoma to limit this type of avoidable blindness.
\end{abstract}

Key words: Glaucoma, late presentation, avoidable blindness, tTrabeculectomy

\section{Resume}

Introduction: Angle d'ouverture du glaucome primaire (AOGP) est l'une des causes principales de la cécité évitable. Contrairement à la cécité de la cataracte dégât au glaucomateuses nerf optique est irréversible, et prévention du glaucome est l'une des priorités de l'Organisation Mondiale de la Santé (OMS), programme du Vision 2020, AOGP est le type de glaucome le plus ordinaire et touche environ 33,1 million de personnes dans le monde. Cette étude est un bilan d'une durée de cinq ans de 71 yeux de 63 malades qui étaient atteints du trabeculectomie. Cette étude fait une évaluation de la tendance de présentation et les modalités du traitement chirurgical dans notre milieu.

Méthodes: Les dossiers médicaux des patients atteints d'angle d'ouverture du glaucome primaire opérés sur une période de cinq ans ont été récupérés. Des informations retirées comprennent des données biologiques des patients, l'acuité visuelle, des résultats gonioscopiques, la pression intra oculaire mesurée avec tonométrie applanation avant et après l'intervention chirurgicale, et enregistré en $\mathrm{mmHg}$. 
La périme trie a été effectuée avec 2 mètres écran tangent et notés dans un tableau périme trie. Tous les patients avaient eu la trabéculectomie avec une application d'anti-métabolite (5fluorovracil). Extraction de la cataracte Extra capsulaire avec ou, sans chambre intraoculaire lentille postérieure d'implantation a été opérée sur 13 patients. La Biométrie n'a pas été fait sur les patients atteints de la cataracte. La chirurgie a été opérée sur un meilleur œil d'abord dans tous les patients.

Résultats: Il y a eu 71 yeux de 63 malades. Le rapport du sexe masculine/sexe féminin était 3:1. L'âge variait entre 18 et 75 ans. 8 patients étaient âgés de moins de 30 ans. Un tiers des patients étaient âgés de 50 à 59 ans. Lors de la présentation 12 des patients soit 19\% avaient une vision normale (OMS vision de la catégorie O), 26 malades soit $41 \%$ étaient malvoyants, 12 soit 19\% ont été gravement malvoyants et 13 patients soit $21 \%$ étaient des aveugles (des cataractes co-existantes). La coupe disc- c (d: d) du rapport évalué avant l'intervention chirurgicale était 0.5 dans 9 yeux soit 13\%, 31 yeux soit 53\% avaient le rapport c.d de 0,6 au 0,8 et 18 yeux avaient le rapport de 0,9 . Tous les patients avaient eu l'angle ouvert de la chambre antérieure (schafer de grade 3 et 4), changements périme triques étaient: doux périphériques de constriction dans 5 yeux soit $8 \%$, constriction périphériques avec arquées scotome dans 19 yeux soit $26 \%$, limites domaines du 30 ou moins en 34 yeux soit $48 \%$, et dans 13 yeux, il était impossible de viser sur l'objectif. IOP avant la chirurgie était 21 à $30 \mathrm{mmHg}$ dans 12 yeux soit $17 \%$ et au dessus de $31 \mathrm{mmHg}$ dans 69 yeux soit 83\%. IOP post opératoire de 10 à $15 \mathrm{mmHg}$ a été obtenue dans 58 yeux soit $82 \%$ et 11 yeux soit $15 \%$ avaient IOP de 16 à $20 \mathrm{mmHg}$. Deux (2) yeux seulement soit 3\% avaient eu IOP dans la basse vingtaine.

Conclusion: L'angle d'ouverture du glaucome primaire est caractérisée par une présentation tardive. La trabeculoectomie avec l'application du $5 \mathrm{Fu}$ est un traitement chirurgical de choix dans notre milieu et donne de bons contrôles intracommunautaires de la pression oculaire. Il est nécessaire de mieux informer le publique sur le glaucome afin de diminuer ce type de la cécité évitable.

\section{Mot clés: Glaucome, présentation tardive,la cécité évitable, trabeculectomie}

\section{Introduction}

Primary open angle glaucoma (POAG) is generally bilateral, although not necessarily symmetrical disease characterized by; glaucomatous optic nerve damage, glaucomatous visual field defects, adult onset, open and normal appearing anterior chamber angles, repeated intra ocular pressure (IOP) $>21 \mathrm{~mm} \mathrm{Hg}$ at some point in the disease (although $15 \%$ or more of those with otherwise characteristic POAG will have IOP consistently below $21 \mathrm{mmHg}$ and are referred to as having normal tension glaucoma), and absence of secondary causes of open angle glaucoma. POAG is the most prominent of all glaucoma's and occurs in 1 in 200 people above the age of 40years. ${ }^{1}$ Glaucoma is one of the leading causes of blindness worldwide. ${ }^{2-4}$ In a population survey of Dambatta district of Kano state, $15 \%$ of those blind and $7 \%$ of those severely visually impaired had glaucoma. ${ }^{5}$ POAG is commoner in blacks as it occurred in 1 in 11 people above the age of 50 years, and 1 in 6 above the age of 70 years. $^{6}$

This study is a retrospective review of 71 eyes of 63 patients operated for primary open angle glaucoma in our hospital between June, 2001 and June, 2006. The aim of the study is to evaluate the pattern of presentation and outcome of surgical management of POAG in our environment.

\section{Patients and Methods}

Records of all patients operated for POAG were retrieved. Information extracted included age, sex, family history of glaucoma, myopia and power of the correction, presence of systemic hypertension, and diabetes mellitus. Visual acuity as measured with Snellen's or, Illiterate " $C$ " charts and recorded for each eye. All patients had basic eye examination. Cup: disc (c: d) ratio was assessed with direct ophthalmoscope. Intra ocular pressure was measured with the applanation tonometer. All patients had indirect gonioscopy using Goldman gonio lens. Perimetry was done with the $2 \mathrm{~m}$ Tangent screen using a $5 \mathrm{~mm}$ white target and recorded on a perimetry chart. Intra ocular pressure was reduced to at least upper twenties with oral acetazolamide and timolol $0.5 \%$ eye drops, before surgery.

All the patients had trabeculectomy with application of 5-fluorouracil (5FU). The procedure included cleaning and draping, application of lid speculum, application of superior rectus bridle suture using 4/0 silk. Limbal based conjuctival flap was raised. Hemostasis was secured with bipolar cautery. A tiny piece of cotton wool soaked with 5\% 5FU was applied over the site of the scleral flap; the conjunctival flap was reflected over the cotton wool and allowed to stay for 5 minutes. The cotton wool soaked with $5 \mathrm{FU}$ was then removed and area washed with $50 \mathrm{mls}$ of normal saline. 5 x $5 \mathrm{~mm}$ outer scleral flap was measured with caliper and raised; an inner triangular flap of $3 \times 3 \mathrm{~mm}$ was raised and excised. Peripheral iridectomy was done. Outer flap was sutured back at four edges using $9 / 0$ silk suture. Anterior chamber was reformed with saline when necessary. For those with associated cataracts, after excision of inner scleral flap, visco elastic material was injected into the anterior chamber $(\mathrm{A} / \mathrm{C})$. This was followed by can opener capsulotomy. The limbal incision was extended on either side of the outer scleral flap edge. Nucleus was delivered by vectis 
extraction. This was followed by irrigation and aspiration of lens cortex. Visco was re introduced in to the $\mathrm{A} / \mathrm{C}$ and posterior chamber intra ocular lens (power of either +19 or, +21 -based on availability) inserted and rotated into position. Dialing was done when required. A peripheral iridectomy was done. The Outer sclera flap was sutured as above and additional interrupted sutures applied on either side of the flap to ensure closure of the corneo scleral incision. Any remaining viscoelastic material was aspirated with Symcoe double cannula. The conjunctiva flap was closed with $6 / 0$ Vicryl ${ }^{\circledR}$.

Patients were placed on topical Mydriacyl, dexamethasone, and Lomefloxacin eye drops four times a day and discharged after 3-5 days. A time interval of 6 to 8 weeks was observed between first and second eye. The eye to be operated first was the better eye in all patients.

\section{Results}

There were 71 eyes of 63 patients, 47 males and 16 females giving a male to female ratio of $3: 1$. The age ranges between 18 years and 75 years (see Table 1 ). 8 patients $(13 \%)$ were below the age of 30 years. Peak age group at presentation was between 50 to 59 years. 20 patients $(32 \%)$ fell into this category. 12 patients (19\%) had visual acuity of 6/6 -6/18 before and after surgery. This is World Health Organization (WHO) vision category $\mathrm{O} .^{7}$ Table2shows that the number of patients with vision category 1 increased from $41 \%$ to $51 \%$. Those with vision category 2 increased from $19 \%$ to $29 \%$. Number of patients with category 3 vision reduced from $21 \%$ to $1 \%$ after surgery. 9 eyes (13\%) had cup: disc (c: d) ratio equal to or less than $0.5,31$ eyes $(54 \%)$ had c: $d$ ratio of 0.6 to 0.8 and in 18 eyes $(33 \%)$ the $\mathrm{c}$ : $\mathrm{d}$ ratio was 0.9 . The $\mathrm{c}$ : $\mathrm{d}$ ratio could not be assessed before surgery in 13 eyes (18\%) due to cataract. In this group the c: $d$ ratio was found to be 0.6 to 0.8 in 7 eyes, and 0.9 in 6 eyes. The intra ocular pressures at presentation are shown in Table 3. 12 eyes (17\%) had IOP $30 \mathrm{~mm} \mathrm{Hg}$ and below, 55 eyes (77\%) had IOP 31 to $50 \mathrm{~mm} \mathrm{Hg}$, only 4 eyes had IOP above $50 \mathrm{~mm} \mathrm{Hg}$ at presentation. Results of perimetry as demonstrated in Table 4 showed that 5 eyes $(7 \%)$ had peripheral field constriction of $10-20 .^{\circ} 19$ eyes $(27 \%)$ had both peripheral field constriction and arcuate scotoma, 34 eyes $(48 \%)$ had visual fields of $30^{\circ}$ and less. In 13 eyes $(18 \%)$ there was in ability to fixate on the target. All patients had open anterior chamber angles on gonioscopy (Shaffer grades 3 and 4). That is anterior chamber angle structures visualized up to scleral spur. Fifty five patients $(87 \%)$ had surgery in one eye (the better eye) and only 8 patients $(13 \%)$ had surgery in both eyes. 7 out of 8 patients in this group were below the age of 40 years. There were 39 right eyes and 32 left eyes. 50 patients (79\%) had trabeculectomy alone, 12 patients $(21 \%)$ had trabeculectomy and extra capsular cataract extraction plus posterior chamber intra ocular lens implantation (ECCE+ PC IOL). The power of PC IOL was either +19 or, +21 diopter sphere. One patient with myopia using minus 15 diopter sphere correction presented with cataract and glaucoma and had trabeculectomy, extra capsular cataract extraction without intra ocular lens implantation. This patient developed posterior capsular opacity at 13-month and Yag capsulotomy was done elsewhere. Biometry was not done in all the patients with cataract.

Post operative IOP of 10 to $15 \mathrm{~mm} \mathrm{Hg}$ was obtained in 58 eyes $(82 \%)$, and 11 eyes $(15 \%)$ had IOP 16 to $20 \mathrm{~mm} \mathrm{Hg}$, only 2 eyes (3\%) had IOP in the lower twenties after surgery. Common immediate post operative complication noted was shallow anterior chamber with positive Siedel's test in 5 eyes $(7 \%)$. This improved with pressure padding. No post operative endophthalmitis recorded. Patients who had trabeculectomy and cataract surgery developed corneal edema with marked anterior chamber inflammation in 9 out of 13 eyes. 3 eyes developed cataracts within 12 to 18 months after surgery and had an uneventful ECCE + PC IOL using superior corneal approach. Only 5 patients (8\%) admitted family history of glaucoma.

Twelve patients (19\%) had associated medical illnesses. Seven had systemic hypertension well controlled on medication, 3 had adult onset (type 2) diabetes mellitus on oral agents for a range of 5 to 10 years. Two patients had both systemic hypertension and diabetes mellitus with poor glucose and blood pressure control.

Table 1. Age and sex distribution of 63 patients with primary open angle glaucoma

\begin{tabular}{lllll}
\hline \multirow{2}{*}{ Age in years } & \multicolumn{2}{c}{ Sex } & Total & \% \\
\cline { 2 - 4 } & Male & Female & 5 & 8 \\
\hline$<19$ & 4 & 1 & 3 & 4 \\
$20-29$ & 3 & - & 10 & 16 \\
$30-39$ & 10 & - & 6 & 10 \\
$40-49$ & 6 & - & 20 & 32 \\
$50-59$ & 13 & 7 & 14 & 22 \\
$60-69$ & 8 & 6 & 5 & 8 \\
$70+$ & 3 & 2 & 63 & 100 \\
\hline Total & 47 & 16 & & \\
\hline
\end{tabular}


Table 2. Visual status before and three months after surgery

\begin{tabular}{lll}
\hline$*$ WHO Vision category & Before surgery & After surgery \\
\cline { 2 - 3 } $\begin{array}{l}\text { No. (Normal) } \\
1 \text { (Visually impaired) }\end{array}$ & $12(19)$ & No. $(\%)$ \\
2 (Severely visually & $26(41)$ & $12(19)$ \\
impaired) & $12(19)$ & $18(51)$ \\
3 (Blind) & $13(21 \%)$ & $1(1)$ \\
\hline Total & $63(100)$ & $63(100)$ \\
\hline * WHO vision category: $0=6 / 6-6 / 18,1=<6 / 18-6 / 60,2=<6 / 60-3 / 60,<3 / 60-N P L$ \\
Source: Manual of international statistical classification of diseases, Injuries and causes of death. Geneva. $1977 ; 46$
\end{tabular}

Table 3. Intra ocular pressure reading of 71 eyes of 63 patients at presentation

\begin{tabular}{ll}
\hline IOP in mmHg & No. of eyes (\%) \\
\hline $21-30$ & $12(17)$ \\
$31-40$ & $26(36)$ \\
$41-50$ & $29(40)$ \\
$50+$ & $4(7)$ \\
\hline Total & $71(100)$ \\
\hline
\end{tabular}

Table 4. Perimetry findings in 71 eyes of 63 patients with primary open angle glaucoma

\begin{tabular}{ll}
\hline Visual fields defect & No. of eyes (\%) \\
\hline Peripheral constriction (mild) & $5(8)$ \\
Above + Arcuate scotomas & $19(26)$ \\
Constricted fields $30^{\circ}$ or less & $34(48)$ \\
Unable to fixate on target & $13(18)$ \\
\hline Total & $71(100)$ \\
\hline
\end{tabular}

\section{Discussion}

Primary open angle glaucoma (POAG) is three times more common in males than females. 45 patients (71\%) were above the age of 40 years in agreement with the pattern in other parts of the world. ${ }^{1} 8$ patients $(13 \%)$ were in their first three decades of life. These belonged to the group of patients with juvenile open angle glaucoma (JPOAG). ${ }^{8}$ JPOAG accounts for $0.02 \%$ of all glaucomas. ${ }^{9}$ Over the 5 -year study period in review, trabeculectomy accounted for $12 \%$ of all surgeries done in our hospital. A population survey in Dambatta local government area of Kano state (where our hospital is located) showed that $15 \%$ of those found to be blind had glaucoma. ${ }^{5}$ Glaucoma is one of the leading causes of blindness worldwide. ${ }^{2-4}$

Glaucoma is always under reported in surveys probably due to different criteria used in definition, testing method used and criteria for making a diagnosis of POAG. ${ }^{10}$ Of an estimate of 66.8 million affected, 33.1 million have POAG. ${ }^{11}$ Most population survey reports indicate that the disease is commoner in blacks than whites ${ }^{12}$ and progresses more rapidly in blacks. ${ }^{13}$ Unlike blindness from cataract, glaucoma blindness is irreversible. ${ }^{14,15}$ The number of patients
SVI or blind reduced due to the change in vision status of the 13 patients who presented with cataracts and glaucoma. This patients' vision improved from blind (category 3) to visually impaired and SVI categories. 1 patient remained blind due to associated long standing chorioretinal scar involving the macular area. POAG affects the quality of life of the individual. $^{16}$

Our patients presented late. Even those who presented earlier and despite intense effort at health education on the nature of the disease, it was difficult to convince some patients that the eye that can see far well has a potentially sight threatening disease. Many factors, some racially inclined contribute to a more aggressive pattern of POAG in blacks. One third of the patients had c: $d$ ratio of 0.9 at presentation. Bowing of the lamina cribrosa is featured as cupping of the optic disc. ${ }^{17}$ At any given intra ocular pressure level greater pressure is exerted on large rather than small optic discs. ${ }^{2,18}$ Large optic disc have been observed in normal, ${ }^{18,19}$ post mortem $^{20}$ and glaucomatous eyes of blacks. ${ }^{21}$

The IOP at presentation was high in most of the patients. Greater optic nerve damage occurs in blacks than white eyes with same level of IOP. ${ }^{22}$ Most of the patients had significant visual field loss at the time of presentation. Blacks of all ages tend to have worst visual fields than whites when $60^{\circ}$ Humphrey's visual field was tested. ${ }^{23}$ Progression of visual field loss is higher in blacks than whites. ${ }^{13}$ The most important risk factors for glaucoma are age, elevated IOP, and family history whereas diabetes mellitus, systemic hypertension and refractive errors are potential risk factors. ${ }^{24}$ Positive family history of glaucoma was obtained in only 5 patients $(8 \%)$. This is not unusual in our environment due to lack of awareness, poor record keeping of medical illness and that most ailments are ascribed to bewitchment and superstition. In developed countries, $50 \%$ of POAG and $43 \%$ with ocular hypertension have a positive family history. ${ }^{25}$ Only 1 patient had high myopia (-15 diopter sphere). Myopia is a mild risk factor for glaucoma. ${ }^{26}$ There is a positive relationship between high myopia and optic disc size. ${ }^{27} 12$ patients (18\%) had associated medical illnesses. 7 had systemic hypertension, and 3 had type 2 diabetes mellitus, 2 had both diseases. Rubeosis iridis as eye complication of diabetes can cause secondary glaucoma. ${ }^{28}$ 
None of these patients had neo-vascularization. Systemic hypertension may accelerate glaucoma damage due to vasoconstriction and closure of small vessels. ${ }^{29}$ Some studies suggested that at the initial stage of systemic hypertension, the high arterial pressure improves optic nerve perfusion and by so doing offers $50 \%$ reduction of POAG mediated damage to the optic nerve at 4 years follow up. ${ }^{30}$ It is often agued the justification for surgical management of POAG. Effectiveness of most anti glaucoma medication is assessed in white rather than black populations. $^{31}$ Newer, safer, more effective, more tolerated drugs are not available to our patients. ${ }^{32}$ Some studies suggest that medical treatment is less beneficial in blacks than whites ${ }^{33}$ and blacks respond less to medical treatment than whites. ${ }^{22}$

In healthy Nigerians, IOP lowering effect of timolol peaked rapidly and faded away in 6 hours $^{34}$ unlike the sustained effect in whites. ${ }^{35}$ Higher concentration of the same drug is required in blacks. Possibly, the drug binds to melanin in ocular tissues such that only a small amount is available to reduce IOP. ${ }^{36}$ Glaucoma medicines are not easily available to our patients in rural areas. ${ }^{37,38}$ Most patients are poor and where these drugs are available they are fake and ineffective. Medical treatment is expensive and compliance is poor. There is long distance between patient and ophthalmologist. ${ }^{39}$ Patient wants visual restoration and eye drops do not restore lost vision ${ }^{40}$ and neither does surgery. It is evident that racial factors play a role in response to treatment modality. ${ }^{41}$ In our study IOP was 10 to $15 \mathrm{~mm} \mathrm{Hg}$ in 58 eyes $(82 \%)$ during a follow up period of 6 -month to 5 years. Anti fibrotic agent such as 5FU may increase the success of trabeculactomy. ${ }^{42}$ Surgery is not risk free as it accelerates cataract formation, and there is risk of visual wipe out phenomenon in those with constricted fields. It does not restore lost sight against the patient's expectation. Argon laser trabeculoplasty (ALT) may have lower long term IOP lowering effect in blacks than whites. ${ }^{43}$ Blacks have higher risk of ALT failure than whites. ${ }^{44}$ In any case lasers are hard to come by in our setting..

Many ophthalmologists in Africa are frustrated and avoid glaucoma surgical treatment. ${ }^{37}$ Cataract, trachoma, onchocerciasis and childhood blindness have committed non governmental organizations (NGO's) with established programs to control these causes of blindness. Glaucoma has no NGO. There is need to increase public awareness of glaucoma with the aim of early detection and intervention. Doctors in general practice should be encouraged to do fundoscopy and identify optic disc cupping and refer suspected cases to ophthalmologists as part of their normal duties. Government needs to provide policy guideline and funding for local training and research on appropriate glaucoma management.

\section{References}

1. Kansky JJ. Clinical ophthalmology. Third edition. Butterworth-Heinemann 1997: 267-273.

2. Butcher PJ, Ijsselmuiden CB. Prevalence and causes of blindness in the northern Transvaal. $\mathrm{Br}$ J Ophthalmol. 1988;72:721-726.

3. Chirambo MC, Schwab L. Ophthalmology in Malawi. Arch Ophthalmol. 1989;107:1826-1829.

4. Fafowora OF, Oshuntokun OO. Age related disease in the elderly members of rural African community. East Afr Med J. 1997;74:435-437.

5. Abdu L. Prevalence and cause of blindness and low vision in Dambatta local government area, Kano state, Nigeria. Niger J Med. 2002;11:108112.

6. Laske MC, Connell AM, Schachat AP, Hyman L. The Barbados Eye Study. Prevalence of open angle glaucoma. Arch Ophthalmol. 1994;112:821-829.

7. Manual of international statistical classification of diseases injuries and causes of death. Geneva. 1977; 46.

8. Bachman JA. Juvenile onset primary open angle glaucoma; three case studies and review. J Am Optom Assoc. 1998;69:785-795.

9. Feid ME, Krupin T. Juvenile glaucoma, in Fraunfelder FT, Roy FH (Eds). Ocular therapy. Philadelpia, WB Saunders Co 1995, pp. 640-643.

10. Schwab L, Kagame K. Blindness in Africa: Zimbabwe school for the blind survey. $\mathrm{Br} \mathrm{J}$ Ophthalmol. 1993;77:410-412.

11. Quigley HA. Number of people with glaucoma worldwide. Br J Ophthalmol. 1996;80:389-393.

12. Mason RP, Kosoko O, Wilson MR, et al. National survey of the prevalence and risk factors of glaucoma in St. Lucia, West Indies. Part 1. Prevalence findings. Ophthalmology. 1989;96:1363-1368.

13. Wilson R, Richardson TM, Hertzmark E, Grant WM. Race as a risk factor for progressive glaucomatous damage. Ann Ophthalmol. 1985;17:653-659.

14. Sommer A, Tielsch JM, Katz J, et al. Relationship between intra ocular pressure and primary open angle glaucoma among white and black Americans. The Baltimore Eye Survey. Arch Ophthalmol. 1991;109:1090-1095.

15. Wallace J, Lovell HG. Glaucoma and intraocular pressure in Jamaica. Am J Ophthalmol. 1969;67:93-100.

16. Alward WL. The genetics of open angle glaucoma: the story of GLCIA and myocilin. Eye. 2000;14:429-436.

17. Quigley HA, Addicks EM, Green WR, Maumenee AE. Optic nerve damage in human glaucoma. II. The site of injury and susceptibility to damage. Arch Ophthalmol. 1981;99:635-649.

18. Chi T, Ritch R, Stickler D, et al. Racial differences in optic nerve parameters. Arch Ophthalmol. 1989;107:836-839.

19. Mansour AM. Racial variation of optic disc size. Ophthalmic Res. 1991;23:67-72.

20. Quigley HA, Brown AE, Morrison JD, Drance SM. The size and shape of optic disc in normal 
human eyes. Arch Ophthalmol. 1990;108:51-57.

21. Martin MJ, Sommer A, Gold EB, Diamond EL. Race and primary open angle glaucoma. Am J Ophthalmol. 1985;99:383-387.

22. Sommer A, Tielsch JM, Katz J, et al. Relationship between intraocular pressure and primary angle glaucoma among white and black Americans. The Baltimore Eye Survey. Arch Ophthalomol 1991; 1090-1095.

23. Rubin GS, West SK, Munoz B, et al. a comprehensive assessment of visual impairment in a population of older Americans. The SEE study. Salisbury Eye Evaluation Project. Invest Ophthalmol Vis Sci. 1997;38:557-568.

24. American Academy of Ophthalmology. Glaucoma in basic clinical science course (section 10). San Francisco, American Academy of Ophthalmology; 2001 pg:11.

25. Shin DH, Becker B, Kolker AE. Family history in primary open angle glaucoma. Arch Ophthalmol. 1977;95:598-600.

26. Curtin B. The Myopias. Basic Science and Clinical Management. Philadelphia, Harper and Row, 1985 pp. 64.

27. Jonas JB, Gusek GC, Naumann GO. Optic disc morphometry in high myopia. Graefes Arch Clin Exp Ophthalmol. 1988;226:587-590.

28. Benson WE, Brown GC, Tasman W. Diabetes and its ocular complications. Philadelphia. WB Saunders, 1988 pp: 67.

29. Tiesch JM, Katz J, Sommer A et al. Hypertension, perfusion pressure and primary open angle glaucoma. A population based assessment. Arch Ophthalmol. 1995;113:216221.

30. Leske MC, Wu SY, Nemesure B, Hennis A. Incident open angle glaucoma and blood pressure. Arch Ophthalmol. 2002;120:954-959.

31. Lawson WB. Clinical issues in pharmacotherapy of African Americans. Psychopharmacol Bull. 1996;32:275-281.

32. Lawson WB. The art and science of the psycho pharmacotherapy of African-Americans. Mt Sinai J Med. 1996;63:301-305.

33. Kass MA, Heuer DK, Higginbotham EJ, et al. The ocular Hypertension Treatment Study: a randomized trial determines that topical ocular hypotensive medication delays or prevents the onset of primary open angle glaucoma. Arch Ophthalmol. 2002;120:829-830.

34. Olateju SO, Ajayi AA. The lack of efficacy of beta-blockers, timolol and betaxolol on intraocular pressure in Nigerian healthy volunteers. Eye. 1999;13:758-763.

35. Katz IM, Hubbard WA, Getson AJ, Gould AL. Intraocular pressure decrease in normal volunteers following timolol ophthalmic solution. Invest Ophthalmol. 1976;15:489-492.

36. Leblanc B, Jezquel S, Davies T, et al. Binding of drugs to eye melanin is not predictive of ocular toxicity. Regul Toxicol Pharmacol. 1998;28:124132.

37. Egbert PR. Glaucoma in West Africa: A neglected problem. $\mathrm{Br} \mathrm{J}$ Ophthalmol. 2002;86:131-132.

38. Silva JC, Bateman JB, Contreras F. Eye disease and care in Latin American and the Caribbean. Surv Ophthalmol. 2002;47:267-274.

39. Lewallen S, Courtright P. Blindness in Africa: Present situation and future needs. $\mathrm{Br} J$ Ophthalmol. 2001;85:897-903.

40. Schwab L, Steinkuller PG. Surgical treatment of open angle glaucoma is preferable to medical management in Africa. Soc Sci Med. 1983; 17:1723-1727.

41. AGIS. The Advanced Glaucoma Intervention Study (AGIS): 4. Comparison of treatment outcomes within race. Seven year results. Ophthalmology. 1998;105:1146-1164.

42. The Fluorouracil Filtering Surgery Study Group. Fluorouracil filtering surgery study, one year follow up. Am J Ophthalmol. 1989;108:625-635.

43. Schwartz AL, Love DC, Schwartz MA. Long term follow up of Argon laser trabeculoplasty for uncontrolled open angle glaucoma. Arch Ophthalmol. 1985;103:1482-1484.

44. AGIS. The Advanced Glaucoma Intervention Study (AGIS): 9. Comparison of glaucoma outcomes in black and white patients within treatment groups. Am J Ophthalmol. 2001;132:311-320. 